\title{
The Development of Handicraft in Watunggere and Nida Village: Ende Regency
}

\author{
Baltasar Taruma Djata \\ Flores University, East Nusa Tenggara, Indonesia \\ Corresponding author email: baltasar.ugm@gmail.com
}

\section{Yohanes Paulus Luciany}

Flores University, East Nusa Tenggara, Indonesia

Email: yohanespaulusluciany@gmai.com

\author{
Kanisius Rambut \\ Flores University, East Nusa Tenggara, Indonesia \\ Email: kanisiusrambut@gmail.com
}

\begin{abstract}
This article explores the development of woven crafts in Watunggere and Nida village, Sub-district Detukeli, Ende Regency. It raises the issue of how the people of Watunggere and Nida developed the woven crafts such as nyiru, bags, baskets, and boxes. These local products have benefits to improve the incomes of the local communities in that area. As well as those products can be promoted to be one of the cultural tourism objects in Ende Regency. To collect the data, this research used the descriptive qualitative and quantitative approach which was completed with several methods such as interview, observation, study documents, and descriptive statistic analysis. Moreover, the analysis of descriptive statistics is used to describe the frequencies of respondents' answers. The results of the research indicate that product design is not regularly done or gained from training, but got from the experiences derived from the ancestors. That is why the model of the product is different from the modern trend. Related to the capability of the workers to design the product is just supported by primary school background. Keywords---product, promotion, supervisor, weaving, woven craft.
\end{abstract}

\section{Introduction}

The development of handicrafts produced in Watunggere and Nida village is a central theme of the study. This title particularly explores three important issues such as the design product, the type of the products, and the problems faced by the craftswomen included the technology of the production and the marketing system or promotion of the products. These three issues will be the central point to be discussed in the next section. This article is specially designed to describe firstly the design of the product, then to present the type of handicraft product in Watunggere and Nida village, and the last is to introduce the problems faced by the craft women in producing the handicraft products included the intervention of technology in producing and the strategy to promote or market the product to be known by wide communities. The result of the research shows that if the government supports the fundings and promotion of the products, of course, the product is a source of the community income and therefore the income of the community of course will be increased (Adrianto \& Mujio, 2004; Anwar \& Gunawan, 2006).

\section{Material and Method}

The information as the basic data that used to analyze the issues of the article are obtained through a qualitative approach and equipped with several methods such as interview and observation, and the documentation study. While 
the quantitative approach is necessary to analyze the quantitative data for example table and graphic. The Validity of data is tested by triangulating the results of the interview, the results of observation, and the results of the documentation study. The data will be analyzed by using the model of analysis promoted by Milles and Huberman. This model indicates the true way to analyze the social-economic issues in the societies. If you want to analyze the social-economic problems, better you follow the steps such as first of all you collect the data, then you reduce the data, after that, you display the data, and based on that, you can draw a conclusion (Bastian, 2001; Mudrajad, 2003). Then, mostly data presented in the form of a table. This makes it easier to analyze the data. The table consists of quantitative data that describe them based on the issues of discussion.

\section{Results and Discussions}

This part is intended to explore the development of handicrafts produced by the local community in Watunggere and Nida village. These two locations are located in sub-district Detukeli, Ende Regency. It will be presented several points which are discussed in the following section (Cooper \& Schindler, 2006; Mudrajad, 2003). First of all, it could be presented how people in those villages designed the handicraft product. Then, the second point has presented the types of handicraft production. Besides that, it could be presented the problems which faced by the craftswomen during they produce the products.

\subsection{Design of handicraft product}

It must be considered when people design the product for several elements such as shape, materials, color, size, functions, and the appropriate ways to produce. This is very important because that good design can be guaranteed the quality of the products (Cahyanto et al., 2009). Referring to the statement that given by Cahyanto, the design of handicraft product that produced by the local community in Watunggere and Nida Village has own shape, materials, color, size, function, and the way to produce. These product elements in that area are different from the handicraft products in other areas on the island of Flores. In connecting with the design of handicraft products in Watunggere and Nida Villages, let us consider the responses of the respondents about the design of handicraft products in the following table.

Table 1

The responses of the respondents about the design of handicraft products in Watunggere and Nida Villages

\begin{tabular}{llllll}
\hline & Frequency & Percent & Valid Percent & $\begin{array}{l}\text { Cumulative } \\
\text { Percent }\end{array}$ \\
\hline Valid & Strongly disagree & 49 & 72.1 & 72.1 & 72.1 \\
& Agree & 4 & 5.9 & 5.9 & 77.9 \\
& Average & 3 & 4.4 & 4.4 & 82.4 \\
& Agree & 2 & 2.9 & 2.9 & 85.3 \\
& Strongly agree & 10 & 14.7 & 14.7 & 100.0 \\
& Total & 68 & 100.0 & 100.0 & \\
\hline
\end{tabular}

Resource: Results of analysis done by the researcher

The table above shows the perceptions of the respondents from Watunggere and Nida village about the design of handicraft products. First, several of the respondents claimed that they strongly disagree if the design of handicraft products done frequently. It means that the design of handicraft products in those villages is passed down from the ancestors.

It is about 49 out of 68 respondents strongly disagree if the design of a product is done frequently or about 72 percent of the respondents strongly disagree if the design product is frequently done, while the respondents who claim quite disagree are about four people or 5.9 percent. Then neutral means that 3 people are out of 68 respondents to average to disagree or it is about 4.4 percent. Meanwhile, two of the respondents agree or 2.9 percent, and the last ten of the respondents strongly agree to the design of handicraft products should be done frequently.

The perceptions of the respondents are different from one to another group because of several reasons. The first reason is most of the respondents are graduated from primary school. Then, according to Simanjuntak, quoted by Utara (2014) claimed that a higher level of education can improve the capability of workers to produce for example handicraft products, and finally can improve the incomes. Although the factor of education influences the capacity of 
the workers to products, the fact shows that the workers of handicrafts in Watunggere and Nida can produce the handicrafts in big numbers and good quality, even they only were graduated from primary school. Furthermore, the skill of weaving has been traditionally educated by their ancestors through their parents, without any formally trained in the non-formal education.

\section{a) The skill of women crafts In Watunggere and Nida Village}

On the other hand, the explanation above shows that the ability or skills in making crafts. According to the craftswomen in Watunggere and Nida villages told that their skill was passed down from their ancestors. Then, parents continue to educate their children. This thing can be seen in the following table.

Table 2

The ability to make the crafts

\begin{tabular}{llllll}
\hline & Frequency & Percent & Valid Percent & $\begin{array}{l}\text { Cumulative } \\
\text { Percent }\end{array}$ \\
\hline \multirow{4}{*}{ Valid } & Very disagree & 65 & 95.6 & 95.6 & 95.6 \\
& Dis agree & 2 & 2.9 & 2.9 & 98.5 \\
& Very agree & 1 & 1.5 & 1.5 & 100.0 \\
& Total & 68 & 100.0 & 100.0 & \\
\hline
\end{tabular}

Source: The results of the analysis done by the research team

This table shows that there are 65 respondents said that they strongly disagree the ability to make the crafts is gained through informal education, for example like a training done by the local government or non-government organization (NGO). In contrast, only two respondents said that she quite agrees the skill of the craftswomen in Watunggere and NidaVilage is gained through training by the government or NGO. While just one respondent said that she strongly agrees the skill of making crafts in Watunggere and Nida village is gained from the training experiences.

The capability of the workers in Watunggere and Nida to produce handicrafts is certainly a skill that is derived from generation to generation. This is a tradition from their ancestors which is called local wisdom and they should conserve and maintain it as well as possible. On the other hand, they have to be responsible for the sustainability of the tradition. Dealing with the local weaving as the wisdom is strongly supported by the idea of Rice as he argues that traditional local weaving has been derived from the ancestors and the handicrafts as a cultural practice are determined by the history or folklore which formulated in the several types of art (Razak et al., 2020; Lee et al., 2002; Pitt \& Lee, 1981).

Moreover, the following data are facts which strongly proved to the statement that the ability of the women crafts in Watunnggere and Nida village is gained from the experiences given by their parents. If we look at the next table, it is indictatedthat59 out of 68 respondents disagree that the skill of weaving is trained by their parents or it is $86.8 \%$ out of $100 \%$. While small numbers of respondents that is 8 respondents or $11.8 \%$ quite agree that the worker's ability to produce the handicrafts are trained by the parents. Moreover, is a very small number of the respondents agree the capability of the workers to produce handicrafts should be trained through the government program. Information related to the training of the craftswomen can be seen in the following table.

Table 3

The capability of the workers to product the handicrafts

\begin{tabular}{llllll}
\hline & Frequency & Percent & Valid Percent & $\begin{array}{l}\text { Cumulative } \\
\text { Percent }\end{array}$ \\
\hline Valid & Very disagree & 1 & 1.5 & 1.5 & 1.5 \\
& Quite agree & 8 & 11.8 & 11.8 & 13.2 \\
& Very agree & 59 & 86.8 & 86.8 & 100.0 \\
& Total & 68 & 100.0 & 100.0 & \\
\hline
\end{tabular}

Source: The results of the analysis done by a research team 
b) The model of the Handicrafts in Watunggereand Nida

According to the Indonesian dictionary called "Kamus Besar Bahasa Indonesia", the word model is form and diversity. Based on the given definition, the term of model product or form of the product can be defined as a thing that has different forms. Related to the form of handicrafts product done by the local community in Watunggere and Nida village has its special characteristics. For these reasons, the following will be presented the answer of the respondents dealing with the statement of the form of the product which has its characteristic. First, it is about $71.1 \%$ or 49 respondents very agree that the handicraft products in Watunggere and Nida have own characteristic. Then, 11 respondents, or about $16.2 \%$ agree that the form of handicrafts products has its characteristics. Whereas 4 respondents or $5.9 \%$ answer so and so that the form of handicrafts has its characteristics. Secondly, it is about $1.5 \%$ or only one respondent does not agree that the form of handicrafts has its characteristics. And lastly, about 3 respondent or $4.4 \%$ very disagree to the statement that the form of handicrafts has own characteristics. The above descriptions can be presented in the form of a table as follows.

Table 4

The form statement of handicrafts has its characteristics

\begin{tabular}{llllll}
\hline & Frequency & Percent & Valid Percent & $\begin{array}{l}\text { Cumulative } \\
\text { Percent }\end{array}$ \\
\hline Valid & Very disagree & 3 & 4.4 & 4.4 & 4.4 \\
& Quite disagree & 1 & 1.5 & 1.5 & 5.9 \\
& Neutral & 4 & 5.9 & 5.9 & 11.8 \\
& Agree & 11 & 16.2 & 16.2 & 27.9 \\
& Very dis agree & 49 & 72.1 & 72.1 & 100.0 \\
& Total & 68 & 100.0 & 100.0 & \\
\hline
\end{tabular}

Source: The results of the analysis done by the research team

c) Model of the Handicraft product follows the trending product

More than that, because the handicraft products in Watunggere and Nida village have their characteristics so that the workers in that area do not create yet new form which is suitable for the new trending product. For this reason, it can be seen from the answers of respondents to the statement: the form of handicraft product which is suitable with the new model. To the statement, there are 51 respondents or $75 \%$ said that they very disagree to follow the new model of handicraft. While 5 respondents or $7.4 \%$ said that they disagree with the statement above and it is about 11 respondents or $16.2 \%$ said that we are in the neutral position. In contrast, there is 1 respondent or $1.5 \%$ said that she agreed to the statement.

Table 5

Model of the Handicraft product follows the trending product

\begin{tabular}{llllll}
\hline & Frequency & Percent & Valid Percent & $\begin{array}{l}\text { Cumulative } \\
\text { Percent }\end{array}$ \\
\hline Valid & Very disagree & 51 & 75.0 & 75.0 & 75.0 \\
& Disagree & 5 & 7.4 & 7.4 & 82.4 \\
& No idea & 11 & 16.2 & 16.2 & 98.5 \\
& Agree & 1 & 1.5 & 1.5 & 100.0 \\
& Total & 68 & 100.0 & 100.0 & \\
\hline
\end{tabular}

In fact, up to now, there is no new model of handicraft products in those villages. This can be seen in the answers of the respondents to the above statement. Firstly, 52 respondents or $76.5 \%$ said that they very disagreed with the statement, and 2 respondents, or $2.9 \%$ disagreed with it. Finally, the rest of the respondents said that they strongly agreed or agreed to the above statement. The explanation as stated above can be seen at the table as follows. 
Table 6

Model of the Handicraft product follows the trending product

\begin{tabular}{llllll}
\hline & Frequency & Percent & Valid Percent & $\begin{array}{l}\text { Cumulative } \\
\text { Percent }\end{array}$ \\
\hline Valid & strongly disagreed & 52 & 76.5 & 76.5 & 76.5 \\
& Disagree & 2 & 2.9 & 2.9 & 79.4 \\
& No idea & 12 & 17.6 & 17.6 & 97.1 \\
& Agree & 1 & 1.5 & 1.5 & 98.5 \\
& Strongly agree & 1 & 1.5 & 1.5 & 100.0 \\
& Total & 68 & 100.0 & 100.0 & \\
\hline
\end{tabular}

Source: Results of the analysis done by the researcher team

\section{d) The Size}

The following table presents the size of handicrafts made by local communities in Watunggere and Nida village diverse. This thing is proved by the answers of the respondents for the statement: The handicraft product in those villages have different sizes from each other. If we look at the total number of respondents is 68 people. Then, from the total number of the respondents, it can be presented that $67.6 \%$ out of $100 \%$ or 46 out of 68 respondents very agree with the statement that handicraft products have different sizes. While 10 out of 68 respondents or $14 \%$ agree that the statement of handicraft products have different sizes. In contrast, 3 respondents, or $4.4 \%$ out of $100 \%$ disagree with the statement of the handicraft product in Watunggere and Nida village have different sizes. Then, 1 of the respondents very disagrees with the statement that handicraft products have different sizes. The rest of the respondents that is about 8 respondents or $11.8 \%$ that state neutral to the statement of the handicraft products have different sizes.

Table 7

Size of product

\begin{tabular}{|c|c|c|c|c|c|}
\hline & & Frequency & Percent & Valid Percent & $\begin{array}{l}\text { Cumulative } \\
\text { Percent }\end{array}$ \\
\hline \multirow[t]{6}{*}{ Valid } & Very disagree & 1 & 1.5 & 1.5 & 1.5 \\
\hline & Disagree & 3 & 4.4 & 4.4 & 5.9 \\
\hline & No idea & 8 & 11.8 & 11.8 & 17.6 \\
\hline & Agree & 10 & 14.7 & 14.7 & 32.4 \\
\hline & Very agree & 46 & 67.6 & 67.6 & 100.0 \\
\hline & Total & 68 & 100.0 & 100.0 & \\
\hline
\end{tabular}

Source: Hasilolahan

The following table presents that the kind of product offered is different. This can be seen in the answers of the respondent in the following section. Firstly, it is about 49 respondents out of 68 or around $72.1 \%$ very agree that the kind of product offered is different, while 8 respondents or $11.8 \%$ stated that the handicraft products must be in different types and the rest of them, around 7 respondents or $10.3 \%$ said that they did not have an idea to the statements of the handicrafts product must be in varian type. Finally, it is around 3 respondents or $4.4 \%$ said that they disagreed with the statement of handicraft products must be in varian types and then just only 1 respondent or $1.5 \%$ said that she very disagreed with the above statement.

Table 8

The statement of handicraft product must be in varian types

\begin{tabular}{llllll}
\hline & Frequency & Percent & Valid Percent & $\begin{array}{l}\text { Cumulative } \\
\text { Percent }\end{array}$ \\
\hline Valid & Really disagree & 1 & 1.5 & 1.5 & 1.5 \\
& Quite disagree & 3 & 4.4 & 4.4 & 5.9 \\
& Neutral ( in between) & 7 & 10.3 & 10.3 & 16.2 \\
\hline
\end{tabular}




\begin{tabular}{lllll}
\hline agree & 8 & 11.8 & 11.8 & 27.9 \\
Really agree & 49 & 72.1 & 72.1 & 100.0 \\
Total & 68 & 100.0 & 100.0 & \\
\hline
\end{tabular}

Source: Processed products

\section{e) The products are not easy to damage}

The woven products made in Watunggere and Nida village are not easy to damage. This statement is supported by the answers of respondents in the interview which was done by the researcher in the location of the study. The answers of the respondents can be described in the form of a table as follows.

Table 9

The products are not easy to damage

\begin{tabular}{llllll}
\hline & Frequency & Percent & Valid Percent & $\begin{array}{l}\text { Cumulative } \\
\text { Percent }\end{array}$ \\
\hline Valid & Very disagreed & 1 & 1.5 & 1.5 & 1.5 \\
& agree & 34 & 50.0 & 50.0 & 51.5 \\
& Very agree & 33 & 48.5 & 48.5 & 100.0 \\
& Total & 68 & 100.0 & 100.0 & \\
\hline
\end{tabular}

Source: Processed products

The table above shows that 33 respondents or $48.5 \%$ said that the woven products are not easy to damage. It means that they are very agreeable to the above statement, while 34 respondents, or $50 \%$ said that they agree that the woven products in Watunggere and Nida village are easy to be damaged. In contrast, it is only one respondent or 1.5 $\%$ argued that the woven products are not easy to be damaged. On the other hand, in the process of weaving the weavers are not supervised by the advisor group. To this statement, the following table shows that 3 respondents or $2.9 \%$ argued that they agree to the above statement and it is just one respondent or $1.5 \%$ that she agrees to the statement of the weavers are not supervised by the advisor group in the process of production. In contrast, 65 respondents, or $95 \%$ claimed that they very disagreed with the statement as described in the previous section.

Table 10

The statement of the weavers are not supervised by the advisor group

\begin{tabular}{llllll}
\hline & Frequency & Percent & Valid Percent & $\begin{array}{l}\text { Cumulative } \\
\text { Percent }\end{array}$ \\
\hline Valid & Very disagreed & 65 & 95.6 & 95.6 & 95.6 \\
& agree & 1 & 1.5 & 1.5 & 97.1 \\
& Very agree & 2 & 2.9 & 2.9 & 100.0 \\
& Total & 68 & 100.0 & 100.0 & \\
\hline
\end{tabular}

Source: the results of the analysis done by the research team

Based on the description as stated above, the weavers in Watunggere and Nida Village need to be guided in the process of making products to improve their capability to do the product. Implications of the meaningful guidance are to be higher up the quality of the product. On the other hand, the women's craft needs advisors or facilitators. This group has an important role to make the product better quality. Several important points that dealt with the ideas are as stated in the following part. First, Advisor Group. This group is giving advice, guidance, and consideration. These things are necessary for the group of workers if they do find problems. The support group does not decide at all, but they just give the way how to solve the problems and then let them decide on their own. The second is Trainer Participatory. This group will facilitate and give several basic skills that are important to improve their capabilities for instance to manage the meetings, bookkeeping, administration, solving problems, and making decisions. The last is Link Person. This is a group to facilitate the relationship between the local communities with the stakeholders and making a Website to develop the group of handicraft workers in Watunggere and Nida Village..http://greenblue-phinisi.blogspot.co.id/2009/06/. 


\subsection{The Types of Handicrafts in Watunggere and Nida Village}

This section presents the kinds of handicraft products produced in Watunggere and Nida village. The craftswomen in that area produce several types of handicrafts such as basket (benga), back basket (Basa), nyiru (kidhe), bag (Kuko), side basket (rembi), mat (te'e), box (wati). These handicrafts have their motif which is very interesting to attract the demands of the consumers.

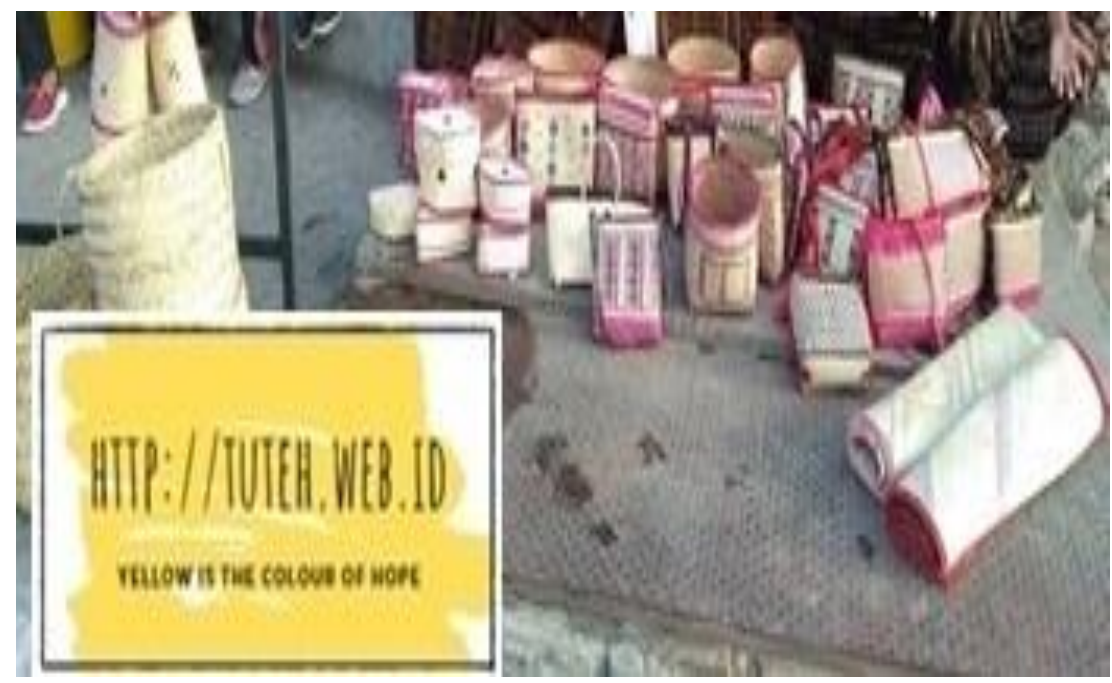

Figure 1. The types of handicrafts in Watunggere and Nida Village

Table 11

The local workers who weave the handicrafts in Watunggere and Nida

\begin{tabular}{|c|c|c|c|c|}
\hline No & Products & Raw Materials & Dye & Significance \\
\hline 1. & Basket (benga) & $\begin{array}{l}\text { Pandan, lontar, and gebang } \\
\text { leaves and ropes of waru } \\
\text { tree }\end{array}$ & dyes, natural dyes & To store food ingredients \\
\hline 2. & Back basket (Basa) & Lontar and gebang Leaves & dyes, natural dyes & $\begin{array}{l}\text { To store food, bittle nut, sacred } \\
\text { items }\end{array}$ \\
\hline 3. & Nyiru (Kidhe) & $\begin{array}{l}\text { Skin of banmboo and } \\
\text { rotan. }\end{array}$ & - & Rice filter \\
\hline 4. & Bag $($ Kuko) & Lontar and gebang leaves & - & To store food, parcel packaging \\
\hline 5. & Side basket (Rembi) & Lontar and gebang leaves. & dyes, natural dyes. & $\begin{array}{l}\text { To store bittle nut, tambaco, } \\
\text { cigarette, stationary }\end{array}$ \\
\hline 6. & MatTe'e) & Pandan Leaves & dyes & $\begin{array}{l}\text { Sitting mat for honorable guests } \\
\text { and traditional elders. }\end{array}$ \\
\hline 7. & BoxWati). & Lontar leaves & - & $\begin{array}{l}\text { To store food, bittle nut, sacred } \\
\text { items in the traditional house, } \\
\text { parcel packaging }\end{array}$ \\
\hline
\end{tabular}

Source: The results of the analysis done by the research team

The local workers who weave the handicrafts in Watunggere and Nida, dominated by women. This job is transformed from generation to generation. It is usually the young girls are the assistance of mothers in working to make handicrafts products as stated in the previous section.

\section{The Wowencrafts}

The respondents informed that the handicrafts products are the works of women. Therefore the workers of handicrafts products are usually called women crafts. They can be grouped into the type of product as shown in the following table. 
Table 12

The women crafts

\begin{tabular}{lll}
\hline Products & Weavers & Percentage $(\%)$ \\
\hline Basket & 64 & 94.12 \\
Back basket & 38 & 55.88 \\
Nyiru & 1 & 1.47 \\
bag & 2 & 2.94 \\
Side basket & 22 & 32.35 \\
Mat & 42 & 61.76 \\
Box & 4 & 5.88 \\
\hline
\end{tabular}

Source: the results of the analysis done by the research team

Based on the above table, it seems that there are three types of handicraft products such as nyiru, bag, and box are less attractive to craftsmen. It can be seen in the answers of the respondents. Is about one or $1.47 \%$ wants to make nyiru, two people make bags, and 4 people make boxes. This happened because goods from outside such as nyiru made of plastic, plastic bag, and plastic boxes thereby reducing the interest of craftswomen to weave them (Siregar, 2015; Sukmara et al., 2001).

\subsection{Problems of productions}

This section is intended to analyze the several problems found in making the handicrafts in Watunggere and Nida villages. The problems are the technology used in the production process, production management, and marketing system of Handicrafts.

1) The technology used in the production process

This part explains the problems with technology, the quality of workers, and the capital. The first is technology. So far, the technology that is used to produce the crafts is very simple. The way they do it is passed down from their ancestor and the tools are used as knives and machetes.

The second is the quality of workers. According to the respondents, they argue that it is about $64 \%$ out of $100 \%$, the craftswomen in the villages of Watunggere and Nida graduated from elementary school, and it is about $2.94 \%$ graduated from secondary education, and while 2,94\% are graduated from Senior high school or vocational high school. This illustrates that the quality of handicraft production is inadequate due to low education. Also, the craftswomen have never attended any training organized by the government or NGOs.

On the other hand, the fact shows that regular training is very important to improve the competitiveness of human resources, especially the craftswomen in Watunggere and Nida Village. Thus, they are still recognized for their existence in the global era (Bisma et al., 2010). Hence, the group of craftswomen in two villages as stated in the previous section must respond to the demands in this global era to be able to improve their skills and expertise so that they can compete in the global market.

The craftswomen in Watunggere and Nida village have not enough skill to make handicrafts of good quality which is caused by two reasons as stated in the previous part. It means that they need to be trained to improve their capacity. Furthermore, the following part, it can be presented the perceptions of the respondents (craftswomen) about the statement: to be participants of the design product activity. Most of them, it is about 88 respondents or $97,1 \%$ argued that strongly disagree if they don't join or attend the training while only two respondent disagree if they do not take part in the design training product. It is tabulated in the following table.

.Table 13

Problems of productions

\begin{tabular}{llllll}
\hline & Frequency & Percent & Valid Percent & $\begin{array}{l}\text { Cumulative } \\
\text { Percent }\end{array}$ \\
\hline Valid & Very disagreed & 66 & 97.1 & 97.1 & 97.1 \\
& disagreed & 2 & 2.9 & 2.9 & 100.0 \\
& Total & 68 & 100.0 & 100.0 & \\
\hline
\end{tabular}


The third is capital. According to Tulus as quoted by Afifah et al. (2012), argues that capital is one of the very important factors for every business, either small scale business, middle-scale business, or the biggest business scale. This thing is supported by Neti as quoted by Afifah et al. (2012), and argued that capital is one of the very important factors, besides the other factors to support the effectiveness of a business.

On the other hand, According to the respondent (Resp. 37,43: 2018) said that capital is the money used for the weaving business. According to the craftsmen's understanding, capital is a budget that can be designed to start a craft business, but 68 respondents have never received budget assistance as business capital. They expect capital assistance from donors or related agencies. In the following, the respondents were divided into three groups, as the first respondent (Resp. 33, 35, 66: 2018) expecting financial assistance, the second respondent (Resp. 37,43:2018)asking for financial assistance to start the business, the last respondent (Resp,38:2018) asking for financial donations. The statement from the respondent group illustrates that it is necessary and sufficient to start a handicraft business for the statement: to get the financial supports to develop the handicrafts products.

But, until now, capital assistance for craftsmen in Watunggere and Nida villages has never been received from any party. This a serious problem found by the craftswomen. For this reason, the following section presented the respondents' perceptions for the statement: getting the financial support to develop the handicrafts products. Is 67 respondents or $98.5 \%$ strongly disagree if they do not get the financial support to develop the handicrafts. It means that most of them do hope to get funds to establish their business in making crafts. It is just one of the respondents or $1.5 \%$ said it is necessary or not to ask the amount of money to help the craftswomen in establishing the handicrafts business. For this thing, it can be seen at the table as follows.

Table 14

The craftswomen in establishing the handicrafts business

\begin{tabular}{llllll}
\hline & Frequency & Percent & Valid Percent & $\begin{array}{l}\text { Cumulative } \\
\text { Percent }\end{array}$ \\
\hline Valid & Very disagreed & 67 & 98.5 & 98.5 & 98.5 \\
& Neutral & 1 & 1.5 & 1.5 & 100.0 \\
& Total & 68 & 100.0 & 100.0 & \\
\hline
\end{tabular}

This table is created by the team based on the analysis

2) Promotion and marketing of handicraft product in Watunggere and Nida Village

Promotion is a one-way flow of information or persuasion designed to direct a person or organization to actions that create exchange or marketing (Dh, 1986). Referring to this definition, efforts to promote or enlarge the handicrafts of the Watunggere and Nida community are the hopes of respondents. The following shows the respondent's statement about product promotion or marketing (Mangold \& Faulds, 2009; Engbers et al., 2005). Respondent 2 (2018) said that handicraft we make can be promoted and sold at a satisfactory price, respondent 3 (2018) said that we need help to promote the woven products, respondent 4 (2018) said that the woven products can be marketed by other parties so that the products we make can be sold with a satisfactory price, respondents 5-9 (2018) argue that "helps to promote handicraft products", Respondent 11 (2018) said that the results of handicrafts can be promoted so that the products can be sold and the money can be used for family purposes, respondent 12 (2018) said that the results of our handicrafts can be promoted elsewhere, respondent 13 (2018) said that the results of our handicrafts can be promoted and sold, respondent 14 (2018) said that handicraft products were promoted and sold so that the money from the sale could be used for living needs.

Respondents 15, 23,24 (2018) said that handicraft products were promoted and finally sold, respondents 25, 27-30, 37 (2018) said that "helps promote handicraft products, respondent 20 (2018) said that handicraft products must be promoted so that they are known to the wider community, respondent 21 (2018) said: they want the handicraft products to be known by many people, respondent 22 (2018) said that handicraft products must be promoted so that they can be recognized in the community, respondent 26 (2018) said that our handicraft products are promoted by others so that these products can be sold and the money is used for living purposes, respondent 50 (2018) said that we hope that our handicraft products can be known outside the region, respondent 52,58 (2018) said that the handicraft products of the Watunggere and Nida community must be promoted so that many people can recognize them, and the last respondent 55 (2018) said that the handicraft products of the Watunggere and Nida community must be promoted so that they can be known by the communities or other areas. Based on the statements conveyed by the respondents above, it can be concluded that all respondents hope that handicraft products should be promoted 
so that they can be known by the general public, which ultimately the handicraft products of the Watunggere and Nida community have economic value for craftswomen (Park \& Lee, 2009; Nagamachi, 1995).

However, the reality faced by craftsmen in Watunggere and Nida villages is less promoted so that it is not well known by the general public. When the respondent is asked to answer the statement: Are there any product promotion activities? 66 people or $97.1 \%$ answered that the lack of promotional activities resulted in the low number of woven products in Watunggere and Nida villages being recognized in the market. So that these products can only be used for souvenirs, family needs, traditional ceremonies, and wedding belis (wurumana). It can be seen in the following table 15 .

\section{a) Budget for promotion}

According to Tulus as quoted by Afifah et al. (2012), argues that capital is one of every important factor for every business, either small scale, middle scale business, or the biggest scale business. This thing is supported by Neti as quoted by Afifah et al. (2012), and argues that capital is one of the very important factors, besides the other factors to support the effectiveness of business. Respondents (37,43: 2018) said that capital is money for handicraft businesses. Capital in their understanding is a budget that can be designed to start a handicraft business. However, the reality is that 68 respondents have never received business capital assistance and the respondents expect budget assistance from the donor, in this case, the related agencies.

The following shows the respondents' statements regarding the budget. Respondents 33, 35, 66 (2018) hope to receive financial assistance soon. Meanwhile, respondents 36.39-46 (2018) requested financial assistance, and respondents 37.43 (2028) requested financial assistance or money for a handicraft business. Finally, respondent 38 (2018) asked for a donation of funds. Thus it can be understood that to carry out handicraft activities requires funds as a budget for business activities. However, in reality, the budget prepared was not in favor of the craftswomen in Watunggere and Nida villages. This can be seen through the answers to the following statements: Receiving assistance in the form of a budget for the development of woven products. 67 people or $98.5 \%$ strongly disagree while 1 person or $1.5 \%$ answered neutrally. Completely presented in table 14 .

\section{b) The Media for promotion}

So far, handicraft products have been promoted through social media such as radio, a local newspaper. Recently it has been promoted through the WA group. This fact indicates that the way of promoting the handicrafts in Watunggere and Nida villages is not effective in introducing these products. That is why these handicraft products are not known by many people.

c) The usefulness of handicraft products

Due to lack of promotion, people can only use it for several purposes such as souvenirs, household needs, traditional ceremonies, and wedding needs. This can be seen in the following table.

Table 15

The use of handicrafts products

\begin{tabular}{ll}
\hline The Use of handicrafts products & Percent $(\%)$ \\
\hline Souvenirs & 16.18 \\
Household necessities & 57.35 \\
Family needs & 39.71 \\
Traditional ceremony & 39.71 \\
Wedding needs & 14.71 \\
\hline Source The resuts of the analysis done by the
\end{tabular}

Source: The results of the analysis done by the research team

Based on the descriptions as stated in the previous section, it can be concluded that there are several factors, influence the development of handicraft products made by the workers in both villages Wantunggere and Nida as follows, such as raw materials, workers, and capitals. 


\section{1) Raw Materials}

Handicraft is an art activity that the row materials are from leaves of Pandan tree, gebang tree, lontar tree, and Bamboo. However, the row materials are provided in limited numbers in the area of the handicrafts produced. Particularly, pandan leaves, gebang leaves, and lontar leaves are very limited. For the time being, the raw materials are still supplied from the two villages such as Watunggere and Nida. Especially, gebang leaves and lontar leaves are bought from the communities that live in the north coastal area of Ende Regency. For this thing, there is $48.61 \%$ of respondents argued that the gebang leaves and lontar leaves come from costal areas mostly located in the north of Ende Regency. The local language says boro no'o koli wiki ghawa me ma'u. It means that gebang leaves and lontar leaves are taken from the part of the costal area.

\section{2) Workers}

According to Jeniarto as quoted by Razak et al. (2020), argued that innovation can change the tradition which heritage from the old generations. Herewith the statement, the results of the research were conducted in Watunggere and Nida Village Detukeli Sub-district, Ende Regency show that the weavers of handicrafts have a less educated background and rarely trained and guided as a result, they could not be creative to make something new in producing handicrafts. Besides that, they work on doing the handicrafts based on the guidance of their parents. Yet, they never got a training program organized by the local government.

\section{3) Capital}

Capital is wealth in the form of money or other assets owned by a person or organization or available or contributed for a particular purpose such as starting a company or investing. The capital itself is provided to run the economic activities effectively as well as those activities can be done efficiently. To run a business smoothly, it is necessary to provide sufficient funds so that the business can be effective and can provide benefits (Afifah et al., 2012). Based on the results of the research done in Watunggere and Nida Village shows that weaving craftswomen find difficulties in the woven crafts business, namely, lack of funds. This is supported by the following respondents. Most of the respondents, about 67 people out of 68 people as a total of respondents argued that the weaving craftswomen need sufficient funds to run handicrafts business. Besides, they said the government had never provided financial assistance for handicrafts business development.

\section{Conclusions}

This section provides a closing statement that includes two things, namely conclusions and suggestions or recommendations. First, it is presented several conclusions and then presented some suggestions which addressed to the readers.

Based on the description in the previous section, it could be concluded some important points as follows.

a) Product design is based on the experiences taught by parents or family. Therefore, the product model has not been able to follow the current trend of the model

b) The ability to design products is still lacking due to several reasons, namely low educators, never having the opportunity for training, and there are no assistants to guide craftswomen.

c) There is a lack of promotion of handicrafts in Watunggere and Nida so that these products are not yet known by the wider community.

\section{Suggestions}

There are several important recommendations to be conveyed to those who are responsible for developing handicrafts in Watunggere and Nida village. The responsible parties are the local village government and the Ende district government.

a) It is important to provide regular training and assistance for craftsmen so that their abilities can be improved and they can be creative and innovative.

b) It is also necessary to promote both through social media and national and international Exhibition activities. So that through this activity the handicraft products of the people of Watunggere and Nida can be recognized by the wider community.

c) The Ende district government needs to prepare companion staff to help craftsmen in Watunggere and Nida villages and each village has one assistant. 
d) Especially for the Watunggere and Nida village governments, it is necessary to establish a Village-Owned Enterprise which functions as a channel for distributing handicrafts from the village community.

\section{Acknowledgment}

The authors would like to express our highest appreciation and gratitude to parties who have given us meaningful assistance to complete this article. Then, the same appreciation and gratitude are delivered to the honorable Chairman of Yapertif, Rector of Flores University, Dean of Economic Faculty, the Head of LP2M Flores University, Regency of Ende District, especially Head of Kesbangpolinmas Institution, our mates, Head of Sub-district and village in the research location, informants who live in the field study, Thanks to all surely have a contribution to complete this research. Finally, we worship and give thanks to God for His support to finish writing this article.

\section{References}

Adrianto, L., \& Mujio, W. Y. (2004). Modul pengenalan konsep dan metodologi valuasi ekonomi sumberdaya pesisir dan laut. Bogor: PKSPL-IPB.

Afifah, A., Ernawati, D., \& Sudaryanto, S. (2012). Faktor-faktor yang berhubungan dengan terjadinya dermatitis kontak akibat kerja

Anwar, C., \& Gunawan, H. (2006). Peranan ekologis dan sosial ekonomis hutan mangrove dalam mendukung pembangunan wilayah pesisir. Makalah Utama pada Ekspose Hasil-hasil Penelitian: Konservasi dan Rehabilitasi Sumberdaya Hutan. Padang, 20, 23-34.

Bastian, I. S. (2001). Akuntansi sektor publik di Indonesia.

Bisma, I., Gde, D., \& Susanto, H. (2010). Evaluasi kinerja keuangan daerah pemerintah Provinsi Nusa Tenggara Barat tahun anggaran 2003-2007. Ganec Swara, 4(3), 75-86.

Cahyanto, I., Pennington-Gray, L., \& Thapa, B. (2009). Reflections from utilizing reflexive photography to develop rural tourism in Indonesia. Tourism Analysis, 14(6), 721-736.

Cooper, D. R., \& Schindler, P. S. (2006). Metode Riset Bisnis,(terjemahan). Volume I dan II, Edisi Sembilan, Penerbit PT Media Global Edukasi, Jakarta.

Dh, B. S. (1986). Imetateori Dalam Perilaku Konsumen Suatu Komparasi Perspektif. Jurnal Ekonomi dan Bisnis Indonesia, 1(1986).

Engbers, L. H., van Poppel, M. N., Paw, M. J. C. A., \& van Mechelen, W. (2005). Worksite health promotion programs with environmental changes: a systematic review. American journal of preventive medicine, 29(1), 6170. https://doi.org/10.1016/j.amepre.2005.03.001

Lee, L., Rudov-Clark, S., Mouritz, A. P., Bannister, M. K., \& Herszberg, I. (2002). Effect of weaving damage on the tensile properties of three-dimensional woven composites. Composite Structures, 57(1-4), 405-413. https://doi.org/10.1016/S0263-8223(02)00108-3

Mangold, W. G., \& Faulds, D. J. (2009). Social media: The new hybrid element of the promotion mix. Business horizons, 52(4), 357-365. https://doi.org/10.1016/j.bushor.2009.03.002

Mudrajad, K. (2003). Metode riset untuk bisnis dan ekonomi. Jakarta: Erlangga.

Nagamachi, M. (1995). Kansei engineering: a new ergonomic consumer-oriented technology for product development. International Journal of industrial ergonomics, 15(1), 3-11. https://doi.org/10.1016/01698141(94)00052-5

Park, C., \& Lee, T. M. (2009). Information direction, website reputation and eWOM effect: A moderating role of product type. Journal of Business research, 62(1), 61-67. https://doi.org/10.1016/j.jbusres.2007.11.017

Pitt, M. M., \& Lee, L. F. (1981). The measurement and sources of technical inefficiency in the Indonesian weaving industry. Journal of development economics, 9(1), 43-64. https://doi.org/10.1016/0304-3878(81)90004-3

Razak, T. B., Roff, G., Lough, J. M., \& Mumby, P. J. (2020). Growth responses of branching versus massive corals to ocean warming on the Great Barrier Reef, Australia. Science of The Total Environment, 705, 135908. https://doi.org/10.1016/j.scitotenv.2019.135908

Siregar, Y. I. (2015). Menggali Potensi Sumber Daya Laut Indonesia. In Makalah disampaikan Pada Workshop Forum Rektor Indonesia USU (Vol. 6).

Sukmara, A., Siahainenia, A. J., \& Rotinsulu, C. (2001). Panduan Pemantauan terumbu Karang Berbasis Masyarakat Dengan Metoda Manta Tow. Proyek Pesisir-CRMP Indonesia. Jakarta, 48. 